\title{
COMMUNICATING WITH RADIO: EXAMINING THE EXPERIENCES AND PERCEPTIONS OF FARMERS IN GHANA
}

\author{
Antwi Evans ${ }^{\mathrm{a}}$, Tham-Agyekum Enoch Kwame ${ }^{\star \mathrm{a}}$, Aidoo Danley Colecraft ${ }^{\mathrm{b}}$, Okorley \\ Ernest Laryea $^{\mathrm{c}}$, Bakang John-Eudes Andivi ${ }^{\mathrm{a}}$, Boansi David ${ }^{\mathrm{a}}$, Asante Bright Owusu ${ }^{\mathrm{a}}$ \\ aDepartment of Agricultural Economics, Agribusiness and Extension, Kwame Nkrumah \\ University of Science and Technology, Kumasi, Ghana \\ bepartment of Agricultural Extension, University of Ghana, Accra, Ghana \\ 'Department of Agricultural Economics and Extension, University of Cape Coast, \\ Cape Coast, Ghana \\ *E-mail: ektagyekum@knust.edu.gh
}

\begin{abstract}
Farm radio programs have become important conduits of change among farmers. The content, delivery, programming, personnel and benefits need to be evaluated in order to enhance its function in extension delivery. This study sought to examine the experiences and perceptions of farmers on their communications with farm radio programs. The research was conducted in the Bosome Freho District in the Ashanti Region of Ghana. The sample size was made of 400 farmers who were selected using the multi-stage sampling technique. To analyze the data, descriptive statistics such as means, standard deviations, frequencies and percentages were used. Results show that: farmers agreed that three of the thematic areas; benefits, delivery and programming meet their expectations and needs. However, they were neutral towards two; content and personnel. Based on the findings, the study makes the following recommendations; that farmers should continue to listen and rely on farm radio programs for the benefits they derive from it, that the Ministry of Food and Agriculture should put together a structured curriculum that will enrich the content for farm radio broadcasting, and that the Ministry of Food and Agriculture should thoroughly train its personnel that handle farm radio broadcasting so that they are always apt for the work.
\end{abstract}

\section{KEY WORDS}

Communication, radio broadcasters, radio content, radio delivery, radio program, experiences, farmers, farm radio, Ghana.

In Ghana, the extension-farmer ratio indicates that on the average one extension agent (excluding cocoa extension officers) provides technical agricultural services and information to about 1850 farmers (MoFA, 2019). Coupled with this challenge are other constraints such as inadequate logistical support, lack of adequate transport, poor road network, and inadequate storage facilities. These have made it difficult for frontline extension officers to have adequate and regular face-to-face interactions with farmers (Asiedu-Darko, 2013; Antwi-Agyei and Stringer, 2021). Extension education has also been criticized for employing ineffective message delivery approaches. Apart from failing to reach most farmers in their communities, agricultural extension services in general have not achieved much success in communicating effectively with resource-poor farmers (Chapman et al., 2003).

Given the limits and problems of agricultural extension systems therefore, there is clearly a potential role for certain mass media to be used to support agriculture (Ani and Baba, 2010; Aker, 2011). The success of agricultural extension and development programs in developing countries largely depends on the nature and extent of use of mass media in mobilization of people for development. The planners in developing countries realize that the development of agriculture could be hastened with the effective use of mass media. Advantages of mass extension methods include increase in the impact of extension staff through rapid spread of information. Many people can be reached within a short time, even in remote areas (Purushothaman et al., 2003). 
While there is widespread belief that mass media channels have the potential to significantly influence opinions and behavioural change, there seems to be little consensus on the degree and scope of these effects. Even though there is ample evidence of extensive research conducted on mass media effects in the developed world over about seven decades (Preiss, Gayle, Burrell, and Allen, 2006), there is a dearth of similar studies in the context of Africa over the same period. The power of the radio as a tool for persuasion, for facilitating modernity and for economic development (Riley, Sood, and Sanni, 2019; Wei, Fischer and Main, 2008; Wolf, 2010; Wabwire, 2013) and community development remains generally unexplored (Ansah, 1994; Amadu and Alhassan, 2018). When the situation in Africa is compared with Latin America and to a lesser extent, Asia, the inadequate information and research data on communication and culture in Africa becomes vivid. Rural based mass media therefore seem most likely to be able to provide new focus in agricultural communication. As the most rapid and efficient means to inform audiences, electronic mass media, in particular, can reach millions of farm families in areas which are beyond the reach of extension personnel (Ani and Baba, 2010; Adikari, 2014). In view of their ability to reaches a large number of people (Kuponiyi, 2000; Wakefield, Loken and Hornik, 2010), mass media generally play the dominant roles in disseminating information to diverse audiences including the rural poor (Wogu, 2018).

Radio is an essential mass medium that almost every member of the society benefits from. It is a vehicle for projecting personality through which it attracts and holds an audience. Adikari (2014) asserts that radio has radicalized the face of human communication and ultimately become a fixed point in the daily lives of humans whereby people are informed, taught, nurtured and reformed by way of relaxation, reinvigoration and resuscitation. This he argued, makes radio as a medium of mass communication being constantly sought after by its ardent listeners. Kuponiyi (2000) perceives radio as a mobilizer and a formidable factor in the new world order in economy, technology and politics. It is best described as the cheapest, safest and the most effective medium of communication available to man. Despite the world wide enchantment with the internet and web-based learning, radio still retains the advantage of being able to serve dispersed, isolated, and disadvantaged communities aspiring to overcome the barriers of illiteracy and physical distance in many countries.

People listen to radio to be informed, entertained and educated. It is assumed that listeners make their own interpretations of a radio program-if the presentation includes something they can relate to, something familiar. This meaning making process is influenced by a variety of factors, such as the radio program topic, design and the socio-cultural variations in experiences, knowledge and cultural dispositions. It is therefore no argument that radio serves as a means of communication. In the aspect of information, radio provides information in terms of news that is, the day-to-day information within and outside the country (Gorman, Keogh, and Clarke, 2018).

Soola (1988) noted that most governments in developing countries employ the use of radio for agricultural communication with the rural poor because of the realisation that extension education suffers from lack of adequate personnel and logistics. Radio is considered as an effective tool to disseminate agricultural information among the farmers and it is the most powerful mass media for broadcasting information quickly. It is a powerful communication medium and people have to depend on radio to meet their needs of information. Radio can reach large audience at the same time. In terms of cost, it is an extremely economical medium as compared to other extension media and methods involving individual and group contacts. Radio is considered as a credible source of information and is taken as authentic, trustworthy and prestigious medium of communication (Davis et al., 2018).

Community radio stations particularly penetrate remote rural communities with their messages and they scale the barrier of illiteracy. They are therefore useful vehicles for bringing to rural communities' information, new ideas and relevant knowledge, especially in agriculture (Chapman, et al., 2003). Farm radio's strength as an extension tool, therefore, is seen in its ability to reach illiterate farmers and provide them with relevant information, technology and skills on all aspects of agriculture in their own language (Gorman, Keogh, 
and Clarke, 2018). The use of farm radio is a potentially useful and cost-effective way to enhance knowledge and technology transfer to farmers to raise agricultural production in developing countries. It can be a vehicle for participatory communication on agricultural information and innovations (Mhlaba and Yusuf, 2020).

Several research findings have established the significance of radio in providing information to farmers. Badiru and Akpabio (2017) found that majority of farmers utilized agricultural information disseminated via radio. In addition, in terms of credibility, Kakade (2013) found that farmers rated radio was at the top as the next credible source of farm information after agricultural extension officers. In terms of awareness, Fawole and Olajide (2012) also reported that radio was utilized as farm a major agricultural information source majority of farmers. Additionally, Cubos and Vargas (2021) found radio as the effective source to be the second most preferred broadcast media source of agricultural information after television.

Farm radio programs can expand and make available information networks for farmers so that they are able to benefit from the knowledge and skills of extension officers and also from other farmers in the communities. Farm radio's strength as an extension tool, therefore, is seen in its ability to reach illiterate farmers and provide them with relevant information, technology and skills on all aspects of agriculture in their own language (Chapman et al., 2003; Kuponiyi, 2000). The farm radio has therefore been identified as a potentially useful and cost-effective way to enhance knowledge and technology transfer to farmers to raise agricultural production in developing countries. It can be a vehicle for participatory communication on agricultural information and innovations. If people have access to communication media they can use them to gain further information (Chapman et al., 2003).

Even though several studies have sought to identify the benefits of the use of farm radio in agricultural extension there still exists a gap regarding farmers' perceptions of the use of farm radio, the benefits involved, as well as the content delivered, among others. For instance, while some studies such as Okwu et al., (2007); Mubangizi, Kyazze and Mukwaya (2018); Musabyimana (2018), Aldosari et al., (2019); Adeyeye et al., (2021) have investigated farmers' levels of radio listenership, their knowledge gain from the radio messages, the agricultural programs broadcast to the farmers, and the relevance of the messages to the information needs of the farmer. However, they did not consider the farmers' perceptions in terms of benefits, personnel, mode of deliver, and the content of the programs broadcast on farm radio. This gap is no different in the context of research conducted in Ghana. Chapman et al., (2003) investigated the impact of radio in disseminating messages on soil and water conservation practices among rural farmers using a radio magazine broadcast for the information dissemination. In addition, Obeng, Gumah and Mintah (2019) looked into Ghanaian farmers' perceptions of the use of information and communication technologies (ICTs) for extension delivery with radio being one of the technologies.

This study therefore attempts to fill a gap by investigating the experiences and perceptions of farmers in their contact with farm radio programs. The specific objectives are to assess farmers' perception about the benefits, personnel, program, delivery and content of farm radio programs.

\section{METHODS OF RESEARCH}

The research was carried in the Bosome Freho District. The study area is located in the south eastern part of Ashanti Region and shares boundaries with Bekwai Municipal and Adansi North District to the West, Ejisu, Juaben and Bosomtwe Districts to the North, Asante Akim South to the East and Akyimansa and Adansi South to the South. It lies within Latitude $6^{\circ} 00^{\prime} \mathrm{N}$ and $6^{\circ} 26^{\prime} \mathrm{N}$ and Longitudes $1^{\circ} 00 \mathrm{~W}$ and $1^{\circ} 30 \mathrm{~W}$. It covers a total land area of about $630 \mathrm{sq}$. $\mathrm{km}$. The study area lies within the forest dissected plateau physiographic region with an average height of between 150 meters and 300 meters above sea level. The topography is relatively flat with occasional undulating uplands, which rise around 240 meters to 300 meters. The highest point is around Lake Bosomtwe area. The area is drained by the Pra, 
Fre, Sunso and Anum rivers which offers great potentials for Agricultural activities all year round. Part of the Lake Bosomtwe lies within the District and offers a great potential for tourism development.

A population is defined as a complete set of individuals, cases or objects with some common observable characteristics (Mugenda \& Mugenda, 2003). In this study, the target population was drawn from the farmers in the Bosome Freho District. The district has 51,338 farmers according to the 2010 Population and Housing Census Report (GSS, 2012). The sample size of this research was calculated by using the Taro Yamane (Yamane, 1973) formula with a $95 \%$ confidence level. The calculation formula of Taro Yamane is presented as follows:

$$
n=\frac{N}{\left[1+N(e)^{2}\right.}
$$

Where: $\mathrm{n}=$ sample size required; $\mathrm{N}=$ number of people in the population; $\mathrm{e}=$ allowable error $(5 \%)$. With a population of 51,338 farmers and a sample size is 397 .

This study used the multi-stage sampling technique. In the first stage, purposive sampling was used in selecting the target district. This is because the district has $85 \%$ of its population as farmers and again eight radio stations are transmitting around the district. According to Engel and Schutt (2010), the purposive sampling method is useful in surveys that target individuals who are knowledgeable about issues under investigation. In the second stage, the simple random sampling technique was used to select ten communities out of the eighty-five communities. In the third stage, the proportional sampling technique was used to select farmers from the selected (10) communities: Adeito- 40, Anyanso- 43, Anumso- 42, Nsuaem- 40, Abosamso- 34, Duase- 42, Korhyikrom- 44, Tebeso II- 32 , Freso- 39 and Dajanso- 41. Primary data was collected for the study in July 2021. Data from the questionnaires were coded and entered into a computer. The computer programs STATA and SPSS were used to analyze the data. Based on five thematic areas (benefits, personnel, program, delivery and content of farm radio programs), farmers were asked to respond to the perception statements. They were asked to respond to each item using a five-point Likert scale with the following ratings: fully agree (5); agree (4); neutral (3); disagree (2) and fully disagree (1). At the end, overall perception scores were calculated for each thematic area. To analyze the data, descriptive statistics such as means, standard deviations, frequencies, and percentages were used.

\section{RESULTS AND DISCUSSION}

The study revealed a mean age of 48 years of respondents in the study area. Age has often been used as a measure of a farmer's experience in the use of farm technology and assessing information from radio agriculture programs. Young farmers, on one hand, may be more knowledgeable about new practices and more prepared to take risk associated with their adoption. Older farmers, on the other hand, may have greater expertise and resources, allowing them to make more informed decision about technology use from listening to farm radio programs (Okwu et al., 2007). The high percentage of young farmers could be attributed to recent programs by Government to encourage young people into farming. The result has implication for agricultural development in Ghana. According to Okwu et al., (2007), age factor is significant in agricultural information accessibility and utilization, since younger farmers are considered to be generally more responsive to new ideas and practices than older farmers. Older farmers are generally conservative and not very responsive to new ideas, agricultural innovations and practices.

The study revealed that male population of farmers interviewed for this study are $63.50 \%$ while the female population interviewed were $36.50 \%$. Okwu et al., (2007) similarly found in their study that there were more males than females. They explained this phenomenon as a fact of males having more access to land than females. It sounds to reason that the males will go into farming than the females. Ordinarily, the society is male- 
dominated in terms of traditional allocation of resources, and this has a direct reflection on ownership and use of cultivable lands. According to Glazebrook (2011), women make immense contribution to food production in Ghana. In spite of this contribution, however, women's development and the prospects of improving their standards of living are low as a result of gender inequalities.

Table 1 - Socio-economic characteristics of farmers

\begin{tabular}{|c|c|c|c|c|c|c|}
\hline Variables & Specification & Mean & Std. Dev. & Freq. (\%) & Min. & Max. \\
\hline Age & Years & 47.67 & 10.14 & 400 & 24 & 80 \\
\hline \multirow{2}{*}{ Sex } & Male & \multirow{2}{*}{\multicolumn{2}{|c|}{$\begin{array}{l}- \\
-\end{array}$}} & $254(63.50)$ & \multirow{2}{*}{\multicolumn{2}{|c|}{ _ }} \\
\hline & Female & & & $146(36.50)$ & & \\
\hline \multirow{5}{*}{ Education } & No formal education & \multirow{5}{*}{\multicolumn{2}{|c|}{ - }} & $2(0.50)$ & \multirow{5}{*}{-} & \\
\hline & Primary & & & $120(30)$ & & \\
\hline & JHS & & & $238(59.50)$ & & \\
\hline & SHS & & & $40(10)$ & & \\
\hline & Tertiary & & & - & & \\
\hline \multirow{4}{*}{ Marital Status } & Single & \multirow{4}{*}{ - } & & $2(0.50)$ & \multirow{4}{*}{ - } & \\
\hline & Married & & & $347(86.75)$ & & \\
\hline & Divorced & & & $47(11.75)$ & & \\
\hline & Widowed & & & $4(1)$ & & \\
\hline Family size & Number & 4.93 & 1.94 & 400 & 1 & 12 \\
\hline Farm Size & Acreage & 7.10 & 3.80 & 400 & 2 & 32 \\
\hline Years of farming & Years & 12.77 & 9.24 & 400 & 2 & 58 \\
\hline \multirow{3}{*}{ Type of farming } & Crops & \multirow{3}{*}{\multicolumn{2}{|c|}{ - }} & 99(24.74) & \multirow{3}{*}{-} & \\
\hline & Livestock & & & $1(0.25)$ & & \\
\hline & Both & & & $300(75)$ & & \\
\hline \multirow{4}{*}{ Land Tenure } & Family land & \multirow{4}{*}{\multicolumn{2}{|c|}{ - }} & $188(47)$ & \multirow{4}{*}{ - } & \\
\hline & Own land & & & $142(35.50)$ & & \\
\hline & Lease & & & $58(14.50)$ & & \\
\hline & Hired/Rented & & & $12(3)$ & & \\
\hline \multirow{3}{*}{ Frequency of receiving extension services } & Sometimes & \multirow{3}{*}{ - } & & $270(67.50)$ & \multirow{3}{*}{-} & \\
\hline & Often & & & $94(23.50)$ & & \\
\hline & Never & & & $36(9)$ & & \\
\hline \multirow{2}{*}{ Access to Radio } & Yes & \multirow[b]{2}{*}{ - } & & $400(100)$ & \multirow[b]{2}{*}{ - } & \\
\hline & No & & & & & \\
\hline
\end{tabular}

Source: Field Data, 2021.

In this study, no respondent had tertiary education, as against JHS which was dominating with a percentage of $59.5 \%$. The study results in Table 1 shows that the majority of respondents (89.5\%) had received some basic form of education i.e. attended primary schools up to JHS. It can be concluded that having completed basic education, i.e. being able to read and write, is a positive indicator of the farmer's ability to process radio agriculture information and find solutions to their production problems. Notably, $10 \%$ of respondents went to secondary school, with no respondent receiving any type of postsecondary education and $0.5 \%$ with no form of education. Low education makes it difficult for farmers to engage in agriculture radio information, resulting in low production. Education is among the key variables often associated with technology use such as radio for agriculture information. Rural education is especially beneficial to rural farmers when new technologies are introduced into agriculture through radio. Therefore, improving rural education is critical for increasing agricultural output and farm incomes, because radio agricultural education may enable farmers to recognize, interpret, and respond to new information from farm radio programs faster than those without formal education.

The kind of activities that a household can engage in, as well as the outcomes of those activities, are influenced by land ownership. According to these findings, the majority of farmers, $47 \%$, farm on family land, $35.5 \%$ of respondents' farm on their farms, $14.5 \%$ farm on lease land and only $3 \%$ farming on rented/hired farmland. The majority of lands in the study area were jointly owned by family members, with the name on the title deed being that of a male family member such as a grandfather, uncle, or husband and that dividing land to 
various sons of the family was not encouraged if the father was still alive at the time of the interview with the respondents.

Respondents had an average family size of 4.93 and an average farm size of 7 acres. One of the housing assets owned by the respondents is the size of land in acres, which includes both productive and non-productive assets owned by rural households. Land, animals, and crops were considered productive assets in the study area, but the style of dwelling held by the family was considered a non-productive asset. The least land size respondents possessed is 2 acres of land where they farm. Majority of respondents had an average farm size of 7 acres.

All respondents in this study had access to radio sets. This means that farmer radio set ownership is a crucial indicator of the information medium available and audience/farmers' exposure to radio agricultural programs is good to gain knowledge, according to Ango et al., (2013) and Okwu et al., (2007). Similar studies on rural farmers in Ghana have indicated equally high radio ownership and radio listenership (Chapman et al., 2003). Chapman et al. (2003) reported that $58 \%$ of the farmers owned radio sets and all of the farmers had access to radio sets any time they wanted to listen to news. Okwu et al., (2007), after a study on 100 farmers, found that $69 \%$ of the sample owned radio sets. In Ghana, portable dry cell batteryoperated radio sets are carried everywhere by farmers, even to the farms, to listen to news and community and rural development broadcasts. In Nigeria, radio ownership is an important factor that determines the physical availability of the medium and exposure of audience to radio agricultural programs (Okwu et al., 2007).

Most of the respondents were married (86.75\%) as against the least representation which was single $(0.5 \%)$. Ghanaians seem to have a lot of preference for polygamy. Majority of people in rural communities still practice polygamy. This could account for the high household populations. Large family sizes are considered an economic advantage in rural communities where the predominant activity is subsistence farming. The average years of farming were 12.77 years. Most of the farmers (75\%) in the study area are into both crops and livestock production. The frequency of receiving extension services recorded a mean of 2.16, which means most of the farmers sometimes receive the services of extension officers.

Table 2 - Perceived benefits of farm radio programs

\begin{tabular}{|l|l|l|l|l|l|l|l|}
\hline Statements & FD, N (\%) & D, N (\%) & N, N (\%) & A, N (\%) & FA (\%) & Mean & $\begin{array}{l}\text { Std. } \\
\text { Dev }\end{array}$ \\
\hline $\begin{array}{l}\text { Farm radio programs help me to make good } \\
\text { decisions about my farming }\end{array}$ & - & - & - & $339(84.75)$ & $61(15.25)$ & 4.15 & 0.36 \\
\hline $\begin{array}{l}\text { Farm radio programs help me to acquire } \\
\text { knowledge }\end{array}$ & - & - & - & $\begin{array}{l}306 \\
(76.50)\end{array}$ & $94(23.50)$ & 4.24 & 0.43 \\
\hline $\begin{array}{l}\text { Farm radio programs help me in solving } \\
\text { problems affecting my farming activities }\end{array}$ & - & $14(3.5)$ & $5(1.25)$ & $\begin{array}{l}294 \\
(73.50)\end{array}$ & $87(21.75)$ & 4.14 & 0.59 \\
\hline $\begin{array}{l}\text { Farm radio programs reach the farmers with } \\
\text { agriculture information }\end{array}$ & - & - & - & $271(67.75)$ & $129(32.25)$ & 4.32 & 0.47 \\
\hline $\begin{array}{l}\text { Farm radio programs have helped in } \\
\text { improving the farming practices of farmers }\end{array}$ & - & - & - & $305(76.25)$ & $95(23.75)$ & 4.24 & 0.43 \\
\hline Overall Index: 4.22 & & & & & \\
\hline
\end{tabular}

Note: FD - Fully Disagree; D - Disagree; N - Neutral; A - Agree; FA - Fully Agree.

Source: Field Data, 2021.

The highest perceived benefit the farm radio program offers to farmers was the perception that farm radio programs reach the farmers with agriculture information $(M=4.32$, $\mathrm{SD}=0.47$ ), followed by how farm radio programs help them to acquire knowledge and how farm radio programs have helped in improving farming practices, both with the mean of 4.24 and standard deviation of 0.43 . The least perceived benefit was the perception that farm radio programs help them in solving problems affecting their farming activities $(M=4.14$, $\mathrm{SD}=0.59$ ). This means that even though the farm radio program is providing farmers with the right agricultural information, nonetheless, it is necessary to address the specific needs of the farmers concerning the type of farming they are involved in. In general, farmers agreed to the benefit statements that were asked (Overall Index=4.22). A positive belief about an object has a high likelihood of leading to a positive feeling or disposition towards the object (Ani and 
Baba, 2010). The agreement among the farmers towards the benefits they get from listening to farm radio programs can evoke high listenership to, and high participation in, the radio station's programs. The degree of perceived benefit ascribed to a communication source, is an important element in the spread of innovations (Bolfe, 2020). Based on the literature on the influence of psychological factors on message uptake, it seems logical to suggest that perceptions of benefits of farm radio would have a positive relationship with farmers' level of listenership to agricultural broadcasts. The results of this study is consistent with that of Adikari (2014) who found that majority of the respondent perceived to benefit from agricultural radio information, particularly in encouraging farmers to diversify their crops for food security. Murumba, Hezron and Mogambi (2017) found that majority of respondents listen to agricultural programs as a source of education to help them improve their farm output. Yahaya and Badiru (2002) also showed that farmers responded most positively to relevant information that they could apply to their own farming and they indicated a perceived need for the programs. According to Okwu et al., (2007), listeners to agricultural programs cited a variety of improved practices they had learned about, and they found the program to be very beneficial in their farming activities. This implies that majority of the farmers in the study area enjoyed the agricultural programs aired and it helps them in improving their level of productivity and income.

Table 3 - Farmers perception on delivery of farm radio programs

\begin{tabular}{|l|l|l|l|l|l|l|l|}
\hline Statements & $\begin{array}{l}\mathrm{FD}, \\
\mathrm{N}(\%)\end{array}$ & $\begin{array}{l}\mathrm{D}, \\
\mathrm{N}(\%)\end{array}$ & $\begin{array}{l}\mathrm{N}, \\
\mathrm{N}(\%)\end{array}$ & $\begin{array}{l}\mathrm{A}, \\
\mathrm{N}(\%)\end{array}$ & $\begin{array}{l}\mathrm{FA}, \\
\mathrm{N}(\%)\end{array}$ & Mean & $\begin{array}{l}\text { Std. } \\
\text { Dev }\end{array}$ \\
\hline Farm radio programs are boring & $83(20.75)$ & $221(55.25)$ & $36(9)$ & $51(12.75)$ & $9(2.25)$ & 2.21 & 0.99 \\
\hline $\begin{array}{l}\text { Farm radio program should be broadcasted } \\
\text { in my local language }\end{array}$ & - & - & - & $266(66.50)$ & $134(33.50)$ & 4.34 & 0.47 \\
\hline The broadcast days are suitable & - & $52(13)$ & $9(2.25)$ & $242(60.50)$ & $97(24.25)$ & 3.96 & 0.89 \\
\hline The broadcast times are suitable & - & $50(12.50)$ & $5(1.25)$ & $232(58)$ & $113(28.25)$ & 4.02 & 0.89 \\
\hline $\begin{array}{l}\text { There are good feedback opportunities } \\
\text { during the broadcast of the farm radio } \\
\text { program }\end{array}$ & $4(1)$ & $71(17.75)$ & $52(13)$ & $231(57.75)$ & $42(10.50)$ & 3.59 & 0.93 \\
\hline Overall Index: 3.62 & & & & & \\
\hline
\end{tabular}

Note: FD - Fully Disagree; D - Disagree; N - Neutral; A - Agree; FA - Fully Agree.

Source: Field Data, 2021.

The highest mean rank of delivery was "farm radio program should be broadcasted in my local language" $(M=4.34, S D=0.47)$. This means that most of the farmers would prefer listening to farm radio programs in their language, so they can relate and associate themselves well with the program. The language utilized in agriculture radio programs makes it understandable, according to Adamides \& Stylianou, (2018), Odira (2014) and Kakade (2013). The second highest mean was the perception that broadcast times are suitable $(M=4.02, S D=0.89)$, which means farmers are comfortable with the delivery times of the program. In a study by Ladele et al., (2014), they found that rural farmers listen to radio most in the evenings because this is the time they are at home and free. As regards the broadcast times of agricultural programs, Ladele et al., (2014) found that $87.7 \%$ of the respondents were satisfied with the times that the radio agricultural programs are broadcasted. There was an indication by the respondents that the broadcast days are suitable $(M=3.96, S D=0.89)$, which also means farmers find the delivery days suitable. The least was the perception that farm radio programs are boring $(\mathrm{M}=2.21, \mathrm{SD}=0.99)$. This means that most of the farmers disagreed that farm radio programs are boring. An earlier study on rural radio audiences revealed that the drama and discussion formats were the most preferred by rural audiences. This is because they made the programs very interesting for listeners to follow (Chapman et al., 2003). In general, farmers agreed to the delivery of farm radio programs (Overall Index=3.62). The study result is consistent with Kakade (2013) and Craig (2001) who found that rural radio was successful in delivering agricultural information to a target groups. Contrary to the findings of this study, Ladele et al., (2014) rather found that there is always a feedback problem because listeners cannot easily contribute to the enlightenment programs. 
The highest mean score of content was the perception that farm radio programs help farmers to prepare ahead for the farming season $(M=4.33, S D=0.47)$. This was followed by farmers' perception of the relevance of topics addressed in the program $(M=3.83, S D=0.66)$ and then, how the content engages their attention $(M=3.67, S D=0.78)$. Rural residents need to be taught how to create their agricultural-related income-generating projects, thus the content must have a significant emphasis tailored to the needs of the listeners. Experts in various fields might be invited to the radio station to address issues in-depth in order to empower farmers to initiate new ventures and bring innovations for development. Myers (2008) observes that radio content of agricultural radio programs help farmers to prepare themselves ahead for the farming season, understand things easily and address the relevant needs of farmers. The overall index of 3.40 shows that the farmers were neutral about the content of the farm radio programs. From the finding of this study, respondents agreed to the majority perception statement asked regarding the content of the program. Unlike the results of this study, Odira (2014) and Nyareza and Dick (2009) found comparable results, concluding that radio farm content was extremely relevant to farmers' requirements. Kakade (2013) also found that majority of farmers opined that the content of agricultural radio programs were fully reliable, easy to understand and the information presented through agricultural radio programs were practicable.

Table 4 - Farmers perception on content of farm radio programs

\begin{tabular}{|l|l|l|l|l|l|l|l|}
\hline Statements & $\begin{array}{l}\mathrm{FD}, \\
\mathrm{N}(\%)\end{array}$ & $\begin{array}{l}\mathrm{D}, \\
\mathrm{N}(\%)\end{array}$ & $\begin{array}{l}\mathrm{N}, \\
\mathrm{N}(\%)\end{array}$ & $\begin{array}{l}\mathrm{A}, \\
\mathrm{N}(\%)\end{array}$ & $\begin{array}{l}\mathrm{FA}, \\
\mathrm{N}(\%)\end{array}$ & Mean & $\begin{array}{l}\text { Std. } \\
\text { Dev }\end{array}$ \\
\hline $\begin{array}{l}\text { Farm radio programs are easy to } \\
\text { understand }\end{array}$ & - & $110(27.50)$ & - & $268(67)$ & $22(5.50)$ & 3.51 & 0.96 \\
\hline $\begin{array}{l}\text { I can easily explain what I learn to other } \\
\text { people }\end{array}$ & - & $138(34.50)$ & $34(8.5)$ & $208(52)$ & $20(5)$ & 3.28 & 0.99 \\
\hline $\begin{array}{l}\text { Farm radio programs help farmers to } \\
\text { prepare ahead for the farming season }\end{array}$ & - & - & - & $269(67.25)$ & $131(32.75)$ & 4.33 & 0.47 \\
\hline The content engages our attention & - & $25(6.25)$ & $134(33.50)$ & $189(47.25)$ & $52(13)$ & 3.67 & 0.78 \\
\hline $\begin{array}{l}\text { The topics addressed in the program } \\
\text { are relevant to the needs of farmers }\end{array}$ & $1(0.25)$ & $8(2)$ & $97(24.25)$ & $248(62)$ & $46(11.50)$ & 3.83 & 0.66 \\
\hline $\begin{array}{l}\text { The content of the program is adult- } \\
\text { centered }\end{array}$ & $159(39.75)$ & $189(47.25)$ & $45(11.25)$ & $5(1.25)$ & $2(0.50)$ & 1.76 & 0.74 \\
\hline Overall Index: 3.40 & & & & & \\
\hline
\end{tabular}

Note: FD - Fully Disagree; D - Disagree; N - Neutral; A - Agree; FA - Fully Agree.

Source: Field Data, 2021.

Table 5 - Farmers perception on Personnel of the farm radio programs

\begin{tabular}{|l|l|l|l|l|l|l|l|}
\hline Statements & $\begin{array}{l}\mathrm{FD}, \\
\mathrm{N}(\%)\end{array}$ & $\begin{array}{l}\mathrm{D}, \\
\mathrm{N}(\%)\end{array}$ & $\begin{array}{l}\mathrm{N}, \\
\mathrm{N}(\%)\end{array}$ & $\begin{array}{l}\mathrm{A}, \\
\mathrm{N}(\%)\end{array}$ & $\begin{array}{l}\mathrm{FA}, \\
\mathrm{N}(\%)\end{array}$ & $\begin{array}{l}\text { Mean } \\
\text { Std. } \\
\text { Dev }\end{array}$ \\
\hline $\begin{array}{l}\text { The presenters always carry the listeners } \\
\text { along }\end{array}$ & $1(0.25)$ & $103(25.75)$ & $11(2.75)$ & $256(64)$ & $29(7.25)$ & 3.53 & 0.96 \\
\hline $\begin{array}{l}\text { Presenters of farm radio programs are } \\
\text { inexperienced }\end{array}$ & $105(26.25)$ & $161(40.25)$ & $14(3.50)$ & $95(23.75)$ & $25(6.25)$ & 2.44 & 1.27 \\
\hline The voice of the presenter sounds unfriendly & $97(24.25)$ & $239(59.75)$ & $11(2.75)$ & $46(11.50)$ & $7(1.75)$ & 2.07 & 0.94 \\
\hline $\begin{array}{l}\text { The presenter brings other experts to join } \\
\text { the program }\end{array}$ & $1(0.25)$ & $6(1.50)$ & $5(1.25)$ & $296(74)$ & $92(23)$ & 4.18 & 0.54 \\
\hline \begin{tabular}{l} 
Overall Index: 3.06 \\
\hline
\end{tabular}
\end{tabular}

Note: FD - Fully Disagree; D - Disagree; N - Neutral; A - Agree; FA - Fully Agree.

Source: Field Data, 2021.

The highest mean score of personnel was the presenter brings other experts to join the program $(M=4.18, S D=0.54)$. This was followed by the presenters always carry the listeners along $(M=3.53, S D=0.96)$ and then, the presenters of farm radio programs are inexperienced $(M=2.44, S D=1.27)$. The overall index of 3.06 shows that the farmers were neutral about the personnel used for the farm radio programs. In terms of the ability of presenters to carry their listeners along, Ladele et al., (2014) found that most presenters are not able to carry their listeners along when presenting on air. They however disagreed that radio broadcasters are inexperienced for the programs they present. 
The highest mean score of program was "there is a commercial break during broadcasting" ( $M=4.35, S D=0.48)$. This was followed by "transmission is consistent" $(M=4.28$, $\mathrm{SD}=0.45)$ and then, "signal quality is appropriate" $(\mathrm{M}=4.32, \mathrm{SD}=0.47)$. The statement with the least figures was "farm radio programs are time consuming" $(M=1.70, S D=0.72)$. This was a negative statement and most farmers disagreed, hence the farm radio program was not timeconsuming. An overall index of 3.74 suggests that farmers agree that farm radio programs need to be maintained as programs for farmers. In terms of signal quality, Zachariah (2008) explained that the radio station a farmer listened to depended much on the availability of air reception of the station and the physical closeness of the radio station to the farmer.

Table 6: Farmers perception on program of the farm radio programs

\begin{tabular}{|l|l|l|l|l|l|l|l|}
\hline Statements & $\begin{array}{l}\mathrm{FD}, \\
\mathrm{N}(\%)\end{array}$ & $\begin{array}{l}\mathrm{D}, \\
\mathrm{N}(\%)\end{array}$ & $\begin{array}{l}\mathrm{N}, \\
\mathrm{N}(\%)\end{array}$ & $\begin{array}{l}\mathrm{A}, \\
\mathrm{N}(\%)\end{array}$ & $\begin{array}{l}\mathrm{FA}, \\
\mathrm{N}(\%)\end{array}$ & Mean & $\begin{array}{l}\text { Std. } \\
\text { Dev }\end{array}$ \\
\hline $\begin{array}{l}\text { Farm radio programs are time- } \\
\text { consuming }\end{array}$ & $159(39.75)$ & $219(54.75)$ & $7(1.75)$ & $12(3)$ & $3(0.75)$ & 1.70 & 0.72 \\
\hline $\begin{array}{l}\text { Time allotted is relatively small } \\
\text { compared to the benefits derived }\end{array}$ & $1(0.25)$ & $61(15.25)$ & $5(1.25)$ & $256(64)$ & $77(19.25)$ & 3.87 & 0.91 \\
\hline The program is well sponsored & $1(0.25)$ & $12(3)$ & $115(28.75)$ & $266(66.50)$ & $6(1.50)$ & 3.66 & 0.56 \\
\hline $\begin{array}{l}\text { Farm radio programs meet my needs } \\
\text { and arouse my farming interest }\end{array}$ & - & $27(6.75)$ & $19(4.75)$ & $275(68.75)$ & $79(19.75)$ & 4.02 & 0.72 \\
\hline Signal quality is appropriate & - & - & - & $274(68.50)$ & $126(31.50)$ & 4.32 & 0.47 \\
\hline $\begin{array}{l}\text { There is a commercial break during } \\
\text { broadcasting }\end{array}$ & - & - & - & $260(65)$ & $140(35)$ & 4.35 & 0.48 \\
\hline Transmission is consistent. & - & - & - & $289(72.25)$ & $111(27.75)$ & 4.28 & 0.45 \\
\hline Perception Index: 3.74 & & & & & \\
\hline
\end{tabular}

Note: FD - Fully Disagree; D - Disagree; N - Neutral; A - Agree; FA - Fully Agree.

Source: Field Data, 2021.

Proximity and familiarity therefore seemed to be important elements that determined which radio station respondents listened to. The reliance of the farmers on farm radio programs as indicated by their agreement to the program suggest that there is a similarity between the source of the information (radio) and the receivers (farmers). The more communication goes on, it is likely to have effect and produce results. Designing and tailoring their programs to meet the needs of the rural folk, perhaps, is one major reason that accounts for the popularity of the farm radio programs in Ghana (Asuman and Diedong, 2019; Zachariah, 2008).

\section{CONCLUSION}

The study examined the experiences and perceptions of farmers in their communications with radio. These were focused on the benefits farmers derive from farm radio programs, the personnel who handle the farm radio programs, the delivery of the farm radio programs, the content of the farm radio programs and the programming of the program. The characteristics of the farmers who were interviewed showed that majority of them are in their youthful ages, they are males, they have completed at least basic school (PrimaryJHS), they farm on family lands, they have an average family size of 4.93 , they have an average farm size of 7 acres, they are married and they have an average years of farming experience of 12.77 years. All of the farmers have access to their own radio sets for listening to farm radio programs.

Based on the overall perception scores, farmers agreed to three of the thematic areas; benefits, delivery and program but were neutral towards content and personnel. The benefits farmers derive from patronizing farm radio programs is numerous; they are reached with agricultural information, it helps them to acquire knowledge, improve farming practices and in solving problems affecting their farming activities. These benefits can evoke high listenership and participation in farm radio programs. In terms of the delivery methods used in organizing farm radio programs, farmers agree that the programs should be broadcasted in their local language so they can relate and associate themselves well with the program. In terms of the 
programming of the farm radio programs, farmers agree that commercial breaks are really helpful while the transmission and signal quality are appropriate.

Based on these findings, the study makes the following recommendations; that farmers should continue to listen and rely on farm radio programs for the benefits they derive from it. The Ministry of Food and Agriculture should thoroughly train its personnel that handle farm radio broadcasting to improve their delivery methods and strategies and their programming of the farm radio. These are essential elements to arouse and sustain the interest of farmers in patronizing farm radio programs. The Ministry of Food and Agriculture should put together a structured curriculum that will enrich the content of farm radio programs for broadcasting. The situation where each radio station does what it feels may be appropriate for its listeners may not be helpful. This is because farm work is different from sports, entertainment, religious or political broadcast where radio stations need to broadcast interesting content to attract more listenership. A structured curriculum for content of farm radio programs will go a long way to improve the food security and livelihoods of the farmers.

\section{REFERENCES}

1. GSS (2012). Population and Housing Census 2010, Ghana Statistical Service, Ghana.

2. Asuman, M. K., \& Diedong, A. L. (2019). Multiplicity of voices in community development through radio in Fanteakwa district, Ghana. Ghana Journal of Development Studies, 16(2), 178-198. https://doi.org/10.4314/gjds.v16i2.9

3. Preiss, R. W., Gayle, B. M., Burrell, N., \& Allen, M. (2006). Mass media effects research: Advances through meta-analysis. Routledge. https://doi.org/10.4324/9780203823453

4. Bolfe, É. L., Jorge, L. A. D. C., Sanches, I. D. A., Luchiari Júnior, A., da Costa, C. C., Victoria, D. D. C., ... \& Ramirez, A. R. (2020). Precision and digital agriculture: Adoption of technologies and perception of Brazilian farmers. Agriculture, 10(12), 653.

5. MoFA (2019). Ministry of Food and Agriculture, https://www.mofep.gov.gh/sites/default/files/pbb-estimates/2019/2019-PBB-MoFA.pdf

6. Asiedu-Darko, E. (2013). Agricultural extension delivery in Ghana: A case study of factors affecting it in Ashanti, Eastern and Northern regions of Ghana. Journal of Agricultural Extension and Rural Development, 5(2), 37-41.

7. Antwi-Agyei, P., \& Stringer, L. C. (2021). Improving the effectiveness of agricultural extension services in supporting farmers to adapt to climate change: Insights from northeastern Ghana. Climate Risk Management, 32, 100304. https://doi.org/10.1016/j.crm.2021.100304

8. Aker, J. C. (2011). Dial "A" for agriculture: a review of information and communication technologies for agricultural extension in developing countries. Agricultural economics, 42(6), 631-647.

9. Wogu, J. O. (2018). Mass media awareness campaign and the prevention of the spread of Lassa fever in the rural communities of Ebonyi State, Nigeria: Impact evaluation. Journal of public health in Africa, 9(3).

10. Wakefield, M. A., Loken, B., \& Hornik, R. C. (2010). Use of mass media campaigns to change health behaviour. The Lancet, 376(9748), 1261-1271. https://doi.org/10.1016/S0140-6736(10)60809-4

11. Adikari, M. P. (2014). Usage of mass media by farmers in Sri Lanka. Developing Country Studies, 4(4), 1-4.

12. Wolf, R. (2010). Radio and Modernity. In The Undivided Sky (pp. 17-45). Palgrave Macmillan, London. https://doi.org/10.1057/9780230251366_2

13. Amadu, M. F., \& Alhassan, A. (2018). Community radio in rural development in Northeastern Ghana: the experiences of radio Gaakii in the Saboba district. International $\begin{array}{llll}\text { Research Journal of Social Sciences, } & 7(5), & 1-12 .\end{array}$ http://www.isca.in/IJSS/Archive/v7/i5/1.ISCA-IRJSS-2018-015.php

14. Wabwire, J. (2013). The role of community radio in development of the rural poor. New Media and Mass Communication, 10, 40-47. 
15. Riley, A. H., Sood, S., \& Sani, M. (2019). Narrative persuasion and social norms in entertainment-education: Results from a radio drama in Mozambique. Health communication. https://doi.org/10.1080/10410236.2019.1606137

16. Wei, M. L., Fischer, E., \& Main, K. J. (2008). An examination of the effects of activating persuasion knowledge on consumer response to brands engaging in covert marketing. Journal of Public Policy \& Marketing, 27(1), 34-44.

17. Ani, A. \& Baba, S. (2010). Utilization of Selected Electronic Mass Media as Sources of Agricultural Information by Farmers in Northern Taraba State, Nigeria. Tropical Agricultural Research and Extension, 12(1), pp.17-22. http://doi.org/10.4038/tare.v12i1.1979

18. Glazebrook, T. (2011). Women and climate change: A case-study from northeast Ghana. Hypatia, 26(4), 762-782. https://doi.org/10.1111/j.1527-2001.2011.01212.x

19. Adeyeye, B., Amodu, L., Odiboh, O., Oyesomi, K., Adesina, E., \& Yartey, D. (2021). Agricultural Radio Programs in Indigenous Languages and Agricultural Productivity in North-Central Nigeria. Sustainability, 13(7), 3929. https://doi.org/10.3390/su13073929

20. Musabyimana, T. Farmers' Perceptions On Mediated Communication of Agricultural Research Results at Rwanda Agriculture Board. International Journal of Innovative Research and Advanced Studies, 5(2), 26-33.

21. Mubangizi, N., Kyazze, F. B., \& Mukwaya, P. I. (2018). Smallholder Farmers' Access and Use of Scientific Climatic Forecast Information in Mt. Elgon Region, Eastern Uganda. International Journal of Agricultural Science, Research and Technology in Extension and Education Systems, 8(1), 29-42.

22. Davis, K. E., Bohn, A., Franzel, S., Blum, M. L., Rieckmann, U., Saravanan, R., ... \& Ernst, N. (2018). What works in rural advisory services? What works in rural advisory services?

23. Fawole, O. P., \& Olajide, B. R. (2012). Awareness and use of information communication technologies by farmers in Oyo State, Nigeria. Journal of agricultural \& food information, 13(4), 326-337.

24. Badiru, I. O., \& Akpabio, N. (2017). Farmers' utilization of Utom Inwang agricultural broadcast on Atlantic FM 104.5 Radio Station, Akwa Ibom State, Nigeria. Journal of Agricultural \& Food Information, 19(4), 377-386.

25. Gorman, M., Keogh, O., \& Clarke, P. (2018). The Use and Potential of Local Radio for Agricultural Extension in the West of Ireland. International Journal of Agricultural Extension, 51-59.

26. Mhlaba, P., \& Yusuf, S. F. G. (2020). Prospects of community radio broadcast as agricultural extension service delivery tool to smallholder farmers in South Africa. Journal for New Generation Sciences, 18(1), 31-44.

27. Cubos, J. T., \& Vargas, D. (2021). Agricultural Information Access Of Farmers Through Rural Radio Agricultural Radio Programs. Available at SSRN 3784724.

28. Obeng, F. K., Gumah, S., \& Mintah, S. (2019). Farmers' Perceptions of Information and Communication Technology (ICT) Use in Extension Service Delivery in Northern Region, Ghana. Ghana Journal of Science, Technology and Development, 6(1), 21-29.

29. Adamides, G. and Stylianou, A. (2018) 'Evaluation of the Radio as an Agricultural Information Source in Rural Areas', Journal of Agricultural and Food Information, 19(4), pp. 362-376. doi: 10.1080/10496505.2017.1401480.

30. Aldosari, F. et al. (2019) 'Farmers' perceptions regarding the use of Information and Communication Technology (ICT) in Khyber Pakhtunkhwa, Northern Pakistan', Journal of the Saudi Society of Agricultural Sciences, 18(2), pp. 211-217. doi: 10.1016/j.jssas.2017.05.004.

31. Ango, A. K., Illo, A. I., Abdullahi, A. N., and Maikasuwa, M. A. (2013) 'Role of Farm-Radio Agricultural Programs in Disseminating Agricultural Technology to Rural Famers for Agricultural Development in Zaria, Kaduna State , Nigeria', 2(1), pp. 54-68.

32. Ansah, P. (1994). Rural Journalism in Africa. Reports and Papers on Mass Communication No. 88. UNIPUB, 345 Park Ave., New York, NY 10010. 
33. Chapman, R., Blench, R., Kranjac-Berisavljevic, G., \& Zakariah, A. B. T. (2003). Rural radio in agricultural extension: the example of vernacular radio programs on soil and water conservation in N. Ghana. Agren Network Paper, 127(2).

34. Engel, R. J., \& Schutt, R. K. (2010). Fundamentals of social work research. Thousand Oaks, CA: Sage. ISBN: 978-1-4129-5416-7, 416 pp

35. Kakade, O. (2013). The credibility of radio programs in the dissemination of agricultural information: A case study of AIR Dharwad, Karnataka. IOSR Journal of Humanities and Social Science, 12(3), 18-22.

36. Kuponiyi F.A. (2000). Mass Media in Agricultural Development: The use of Radio by Farmers of Akinyele Local Government Area of Oyo State, Nigeria. Nigeria Agricultural Development Studie. 1(1):26-32.

37. Murumba, S. R. and Hezron Mogambi, P. (2017) 'Radio for farming? An analysis of regional Radio programs and Agricultural Productivity in Kenya', International Journal of Humanities and Social Science, 7(2), pp. 1-20.

38. Nyareza, S. and Dick, A. L. (2009) 'Use of community radio to communicate agricultural information to Zimbabwe's peasant farmers', pp. 494-508. doi: $10.1108 / 00012531211263111$.

39. Odira, R. A. (2014). The Role of Radio Broadcasting In Enhancing Farm Production In Rural Kenya: A Case Of Radio Nam Lolwe In Kakelo Location, Homa Bay County. pp. 71-79

40. Okwu, O.J., Kuku, A.A. and Aba, J.I., (2007). An assessment of use of radio in agricultural information dissemination: a case study of radio Benue in Nigeria. African Journal of Agricultural Research, 2(1), pp.14-18.

41. Purushothaman, C., Kavaskar, M., Reddy, Y. A., \& Kanagasabapathi, K. (2003). „Role of mass media in agriculture-Global Communication Research Association Center for International Communication, Macquarie University, Sydney, Australia GCRA-Varanasi Conference. COTUL Proceeding 2014.

42. Soola, E.A. (1988). Agricultural Communication and the African non-illiterate farmer: The Nigerian Experience. Africa Media Review Vol. 2 No3, 1988: 75-91

43. Yahaya, M. K. and Badiru, O. I. (2002). Measuring the Impact on Farmers of Agricultural Radio and Television Programs in Southwest Nigeria," Journal of Applied Communications: Vol. 86: Iss. 3.

44. Ladele, A. A, Ladigbolu, T. A and Badiru, I. O. (2014). Factors Affecting the Listenership of Enlightenment Programs on University of Ibadan Community Radio, Proceedings, 19th Annual National Conference of the Agricultural Extension Society of Nigeria held at the Federal University of Agriculture, Owerri, Imo State (27th - 30th April, 2014). 